\title{
DODATKOWE UMOWY STRON W STOSUNKU PRACY W ŚWIETLE ZASADY UPRZYWILEJOWANIA PRACOWNIKA
}

\section{UWAGI WPROWADZAJĄCE}

Strony stosunku pracy mają ograniczoną swobodę umownego kształtowania swoich praw i obowiązków ${ }^{1}$, co jest jednym $\mathrm{z}$ przejawów funkcji ochronnej prawa pracy ${ }^{2}$. Najważniejszą normę ograniczającą wolność kontraktowania stron stosunku pracy wyprowadza się z przepisu art. 18 k.p. Zgodnie z jego treścią postanowienia umów o pracę oraz innych aktów, na podstawie których powstaje stosunek pracy, nie moga być mniej korzystne dla pracownika niż przepisy prawa pracy $(\S 1)$, będą one bowiem uznane za nieważne, a w ich miejsce zastosowanie znajda odpowiednie przepisy prawa pracy $(\$ 2)$. Z tak sformułowanego przepisu rekonstruuje się w literaturze jedną bądź więcej zasad prawa pracy ${ }^{3}$ Z Z reguły jednak tylko dwie: zasadę uprzywilejowania pracownika $^{4}$ (rzadziej zwaną zasadą ochrony uprawnień pracowniczych ${ }^{5}$ ) oraz zasadę automatyzmu prawnego ${ }^{6}$. Można spotkać się również z poglądem, że ta ostatnia jest sankcją za naruszenie zasady uprzywilejowania pracownika, a zatem stanowi jej część składową ${ }^{7}$. Problematyka procesu wyodrębniania

${ }^{1} \mathrm{Na}$ temat granic swobody stron w kształtowaniu treści stosunku pracy zob. w szczególności: B. Wagner, Zakres swobody umów w pracowniczym stosunku pracy, „Zeszyty Naukowe Uniwersytetu Jagiellońskiego" 1987, nr 113; eadem, O swobodzie umowy o prace raz jeszcze, w: M. Matey-Tyrowicz, L. Nawackiego, B. Wagner (red.), Prawo pracy a wyzwania XXI wieku. Ksiega jubileuszowa Profesora Tadeusza Zielińskiego, Warszawa 2002, s. 359 i n.; L. Kaczyński, Zasada swobody umów w prawie pracy po nowelizacji kodeksu pracy, „Państwo i Prawo” 1997, z. 3, s. 8 i n.

${ }^{2} \mathrm{Na}$ temat funkcji ochronnej pisali dawniej m.in. W. Szubert, Funkcje prawa pracy, „Państwo i Prawo" 1971, z. 3-4; L. Florek, Ochrona praw i interesów pracownika, Warszawa 1990; W. Muszalski, Przemiany funkcji ochronnej i organizacyjnej prawa pracy, „Praca i Zabezpieczenie Społeczne” 1995, nr 3. Później problem ten podnosił m.in. Z. Niedbała, Postulaty tzw. uelastycznienia Kodeksu pracy a funkcja ochronna prawa pracy, „Prawo i Administracja” t. 1, red. R. Budzinowski, Piła 2002. Ostatnio zaś szeroko przeanalizował to zagadnienie M. Skapski, Ochronna funkcja prawa pracy $w$ gospodarce rynkowej, Kraków 2006.

${ }^{3}$ Najwięcej, gdyż aż cztery, wyodrębnił W. Sanetra, w: J. Iwulski, W. Sanetra, Komentarz do Kodeksu pracy, Warszawa 2009, s. 128.

${ }^{4}$ T. Liszcz, Prawo pracy, Warszawa 2006, s. 80.

${ }^{5}$ K. Rączka, w: M. Gersdorf, K. Rączka, M. Raczkowski, Kodeks pracy. Komentarz, Warszawa 2010, s. 73 .

${ }^{6}$ U. Jackowiak, W. Uziak, A. Wypych-Żywicka, Prawo pracy. Podręcznik dla studentów prawa, Kraków 2003, s. 61 i n.

${ }^{7}$ E. Chmielek-Łubińska, Szczególne wtaściwości źródet prawa pracy (zagadnienia wybrane), w: A. Swiątkowski (red.), Studia z zakresu prawa pracy i polityki społecznej, Kraków 1999-2000, s. 55. 
zasad prawa pracy jest tematem budzącym kontrowersje ${ }^{8}$, toteż bez wchodzenia $\mathrm{w}$ tym miejscu $\mathrm{w}$ związane $\mathrm{z}$ nią spory, przyjęte zostanie dla uproszczenia, że zasada uprzywilejowania pracownika zawiera $\mathrm{w}$ sobie również mechanizm zastępowalności mniej korzystnych dla pracownika postanowień umownych odpowiednimi przepisami prawa pracy.

Z konstrukcji językowej przepisu art. 18 § 1 k.p. wynika, że zakres jego stosowania ogranicza się tylko i wyłącznie do postanowień umów lub aktów będących podstawą nawiązania stosunku pracy, a zatem zdarzeń wyczerpująco wskazanych w art. 2 k.p. Nie wydaje się jednak, aby zawężenie stosowania zasady uprzywilejowania pracownika do sytuacji literalnie wskazanych w art. $18 \S 1$ k.p. było zabiegiem uzasadnionym. Wskazuje na to szereg argumentów, w tym między innymi wynik pełnego procesu wykładni tegoż przepisu, uwzględniający również dyrektywy funkcjonalne i celowościowe. Poruszony tutaj problem nie jest nowy, a mimo to nadal nie ma zgodności co do jego rozwiązania. W literaturze można spotkać autorów, którzy wyraźnie sprzeciwiają się stosowaniu art. 18 k.p. do innych zdarzeń prawnych niż wprost w nim wymienione ${ }^{9}$, jak również tych, których sprzeciw jest nieco bardziej zawoalowany ${ }^{10}$. Reprezentowane przez nich stanowisko opiera się w głównej mierze na dosłownym brzmieniu przepisu art. 18 k.p., a zatem - przede wszystkim na dyrektywach językowych wykładni. W opozycji do nich znajduje się liczna grupa badaczy, którzy są mniej lub bardziej skłonni rozszerzyć zakres zastosowania tego przepisu również na inne umowy związane ze stosunkiem pracy ${ }^{11}$. Problem jednak w tym, że ci ostatni z reguły nie argumentują szerzej swojego stanowiska, ograniczając się jedynie do przywołania niektórych orzeczeń sądowych. Problem dodatkowo polega na tym, że orzecznictwo nie jest w tym względzie jednolite, choć rzeczywiście zdaje się przeważać linia proochronna, uznająca dodatkowe umowy prawa pracy za objęte regulacja art. 18 k.p. ${ }^{12}$

\footnotetext{
${ }^{8}$ Obszernie i ciekawie na ten temat piszą m.in. M. Piekarski, Podstawowe zasady prawa pracy, „Annales UMCS”, sec. G, 1977, t. 24, s. 37 i n.; W. Perdeus, Proces wyróżniania zasad prawa pracy, „Annales UMCS”, sec. G, 1983, t. 30, s. 59 i n.; T. Zieliński, Zasady prawa pracy w nowym systemie ustrojowym, „Państwo i Prawo” 2001, z. 12, s. 8 i n.

${ }^{9}$ M. Barzycka-Banaszczyk, Kodeks pracy. Komentarz, Warszawa 2008, s. 39 i n.; P. Wąż, Zobowiazania wekslowe $w$ prawie pracy (na tle zagadnienia odpowiedzialności materialnej pracownika), „Praca i Zabezpieczenie Społeczne” 2007, nr 12, s. 26.

${ }^{10}$ A. M. Swiątkowski, Kodeks pracy. Komentarz, Warszawa 2010, s. 511.

${ }^{11}$ M. T. Romer, Prawo pracy. Komentarz, Warszawa 2010, s. 733 i 745; E. Maniewska, w: K. Jaśkowski, E. Maniewska, Kodeks pracy, t. 1: Komentarz, Warszawa 2009, s. 81; R. Sadlik, Zakaz pogarszania sytuacji pracowników w klauzulach umownych, „Monitor Prawa Pracy” 2009, nr 1, s. 23 i n.; B. Wagner, w: eadem (red.), Kodeks pracy 2010. Komentarz, Gdańsk 2010, s. 80; L. Florek, Ustawa i umowa w prawie pracy, Warszawa 2010, s. 125 i n.; K. Walczak, w: W. Muszalski (red.), Kodeks pracy. Komentarz, Warszawa 2009, s. 417; W. Muszalski, w: idem (red.), op. cit., s. 539.

${ }^{12}$ Co do umowy o wspólnej odpowiedzialności materialnej zob. wyrok SN z 24 lutego 1982 r., IV PR 21/82, niepubl. oraz uchwała SN z 4 października 1994 r., I PZP 41/94, OSNAP 1995, nr 5, poz. 63. Co do umów o kształcenie zawodowe pracowników zob. uchwała SN z 27 kwietnia 2005 r., II UZP 2/05, OSNP 2005, nr 21, poz. 338; wyrok SN z 28 lipca 1999 r., I PKN 180/99, OSNAPiUS 2000, nr 21, poz. 789; uchwała SN z 10 marca 2005 r., II PZP 2/05, OSNP 2005, nr 16, poz. 240, z glosa M. Włodarczyka, OSP 2006, nr 6, poz. 76. Co do umów o zakazie konkurencji zob. wyrok SN z 17 grudnia 2001 r., I PKN 742/00, OSNAPiUS 2003, nr 24, poz. 588; wyrok SN z 5 grudnia 2002 r., I PKN 575/01, OSNP 2004, nr 11, poz. 190; uchwała SN z 3 grudnia 2003 r., III PZP 16/03, OSNPUS 2004, nr 7, poz. 116; wyrok SN z 16 czerwca 2005 r., I PK 260/04, OSNP 2006, nr 9-10, poz. 145.
} 
Problem dopuszczalności oceny postanowień umów niebędących podstawą nawiązania stosunku pracy $\mathrm{w}$ świetle zasady uprzywilejowania pracownika jest nie tylko ciekawym zagadnieniem teoretycznym, ale ma również doniosłe znaczenie praktyczne. Strony stosunku pracy bardzo często, oprócz podstawowej umowy o pracę, zawierają ze sobą również dodatkowe kontrakty, mające uszczegółowić ich prawa i obowiązki. Do tych najpopularniejszych należą między innymi umowa o zakazie konkurencji, umowa o wspólnej odpowiedzialności materialnej czy umowa o podnoszeniu kwalifikacji zawodowych przez pracownika. Charakter prawny tych umów nie jest do końca jasny, choć wydaje się dominować stanowisko uznające, że są to tak zwane klauzule autonomiczne ${ }^{13}$. Przy tej okazji pojawia się również problem zawierania przez pracownika i pracodawcę umów nienazwanych i ich wpływu na treść stosunku pracy ${ }^{14}$. $\mathrm{Z}$ tymi zagadnieniami wiąże się pytanie między innymi o rolę zasady uprzywilejowania pracownika przy ocenie postanowień wskazanych wyżej umów. Trzeba zatem rozstrzygnąc, czy wyrażona w art. 18 k.p. zasada uprzywilejowania pracownika znajduje zastosowanie tylko do oceny postanowień wskazanych w nim zdarzeń prawnych, czy dodatkowo, chroniąc całokształt treści stosunku pracy, znajdzie zastosowanie również w niewymienionych literalnie $\mathrm{w}$ tym przepisie przypadkach.

Treść zasady uprzywilejowania pracownika, rozumianej jako norma wyznaczająca minimalny poziom uprawnień i maksymalny poziom obowiązków pracownika, wydaje się zdecydowanie szersza niż literalne brzmienie przepisu art. 18 k.p., który to przepis stanowi jedynie pewien jej przejaw. Mówiąc precyzyjniej, wyrażona $\mathrm{w}$ tym przepisie zasada chroni całokształt treści stosunku pracy, a nie tylko ten jego fragment, który wynika ze zdarzeń prawnych będących podstawa jego nawiązania. Zasada uprzywilejowania pracownika powinna zatem znaleźć zastosowanie również do innych umów zawieranych między pracownikiem i pracodawcą, o ile ich postanowienia składają się na treść stosunku pracy. Za tak sformułowanym stanowiskiem przemawiają co najmniej trzy argumenty. Po pierwsze, obecność mechanizmów charakterystycznych dla zasady uprzywilejowania pracownika również $\mathrm{w}$ innych niż art. 18 k.p. regulacjach prawa pracy, a w szczególności w samym charakterze dominujacych $\mathrm{w}$ prawie pracy norm semiimperatywnych. Po drugie, istota zasady uprzywilejowania pracownika jako normy ogólnej i podstawowej dla całego systemu prawa pracy, a także jej umiejscowienie w systematyce Kodeksu pracy. Po trzecie wreszcie, za takim stanowiskiem przemawia również wynik pełnego procesu wykładni przepisu art. 18 k.p., uwzględniający w szczególności dyrektywy funkcjonalne i celowościowe.

${ }^{13}$ Pojęcie to wprowadził po raz pierwszy M. Święcicki, Prawo pracy, Warszawa 1968, s. 186. Zob. też: W. Piotrowski, Stosunek pracy, Poznań 1977, s. 39 i n.; A. Chobot, A. Kijowski, Nowa koncepcja zobowiazaniowego stosunku pracy, „Ruch Prawniczy, Ekonomiczny i Socjologiczny” 1988, z. 4; T. Bińczycka-Majewska, Zmiana treści umownego stosunku pracy, Warszawa 1985, s. 15 i n.

${ }_{14}$ P. Prusinowski, Nienazwane umowy zawierane przez strony stosunku pracy, „Monitor Prawniczy” 2011, nr 20. 


\section{ZASADA UPRZYWILEJOWANIA PRACOWNIKA W INNYCH NIŻ ART. 18 K.P. PRZEPISACH PRAWA PRACY}

Najszerzej i najdobitniej uniwersalność zasady uprzywilejowania pracownika widać $\mathrm{w}$ samym charakterze dominujacych $\mathrm{w}$ prawie pracy norm semiimperatywnych ${ }^{15}$. Jeśli bowiem semiimperatywna norma prawa pracy ma tę właściwość, że w sposób imperatywny ochrania pewne minimum interesu tylko jednej ze stron stosunku pracy (w tym wypadku pracownika), to czymże w swej istocie różni się jej mechanizm od założeń, jakie legły u podstaw zasady uprzywilejowania pracownika? Co więcej, wydaje się, że można nawet uznać, że istnienie na gruncie prawa pracy tak licznych norm o charakterze semiimperatywnym jest szczególnym przejawem realizacji przez ustawodawcę zasady uprzywilejowania pracownika, co potwierdza dobitnie szeroka skalę jej oddziaływania na całokształt treści stosunku pracy, nie zaś tylko na treść umowy o pracę (lub innych podstaw nawiązania stosunku pracy).

Przedstawione wyżej tezy potwierdza również fakt, że poza art. 18 k.p. $\mathrm{w}$ wielu innych przepisach prawa pracy pojawia się identyczny lub podobny mechanizm chroniący sytuację prawną pracownika przed jej niekorzystnym ukształtowaniem. Dla przykładu jedynie można wskazać art. 9, art. $103^{4}$, art. $241^{13} \S 2$ oraz art. $241^{26} \S 1$ k.p.

Z przepisu art. 9 k.p. wynika, że zasada uprzywilejowania pracownika rozciąga się również na hierarchię aktów prawnych z zakresu prawa pracy, a w szczególności tych o charakterze specyficznym, to jest układów zbiorowych pracy, porozumień zbiorowych, regulaminów i statutów $(\S 1)^{16}$. Postanowienia układów zbiorowych pracy i porozumień zbiorowych oraz regulaminów i statutów nie moga bowiem być mniej korzystne dla pracowników niż przepisy Kodeksu pracy oraz innych ustaw i aktów wykonawczych $(\S 2)$, a dodatkowo postanowienia regulaminów i statutów nie mogą być dla nich mniej korzystne niż postanowienia układów zbiorowych pracy i porozumień zbiorowych $(\S 3)$. Jeśli do tego uwzględnimy również przepis art. $241^{26} \S 1 \mathrm{k} . p$., stanowiący, że postanowienia układu zakładowego nie moga być mniej korzystne dla pracowników niż postanowienia obejmującego ich układu ponadzakładowego, to będziemy mieli pełny obraz wzajemnych relacji źródeł prawa pracy ustalonych przez ustawodawcę na podstawie mechanizmu właściwego zasadzie uprzywilejowania pracownika. Treść stosunku pracy jest zatem chroniona przed niekorzystną dla pracownika zmianą zarówno wynikającą z woli indywidualnej (umowa o pracę), jak i woli kolektywnej (zbiorowe prawo pracy). Co ciekawe,

\footnotetext{
${ }^{15} \mathrm{~W}$ doktrynie uznaje się, że występowanie norm pośrednich jest szczególną właściwością prawa pracy. Tak m.in. G. Goździewicz, Szczególne wtaściwości norm prawa pracy, Toruń 1988, passim; oraz W. Szubert, Szczególne wtaściwości prawa pracy, „Studia Prawno-Ekonomiczne” 4, 1970, s. 53 i n. Zob. również L. Kaczyński, Zasada uprzywilejowania pracownika w świetle kodeksu pracy, „Państwo i Prawo" 1984, z. 8, s. 60 i n.; J. Stelina, w: K. W. Baran (red.), Zarys systemu prawa pracy. Część ogólna prawa pracy, t. 1, Warszawa 2010, s. 237 i n.

${ }_{16}$ Tak również m.in. M. Skąpski w: Z. Niedbała (red.), Prawo pracy, Warszawa 2010, s. 53 i n.; A. Dubowik, Zasada automatyzmu prawnego $i$ uprzywilejowania pracownika po nowelizacji prawa o uktadach zbiorowych pracy, „Praca i Zabezpieczenie Społeczne” 2001, nr 5.
} 
jeśli przyjrzeć się, choćby tylko pobieżnie, przepisowi art. $241^{13} \S 2$ k.p., można dojść do wniosku, że ustawodawca chroni treść stosunku pracy wynikająca z aktów zbiorowego prawa pracy między innymi poprzez instytucje charakterystyczne indywidualnemu prawu pracy (art. 42 k.p.). Zgodnie bowiem z treścią art. $241^{13} \S 2$ k.p. postanowienia układu mniej korzystne dla pracowników wprowadza się w drodze wypowiedzenia pracownikom dotychczasowych warunków umowy o pracę lub innego aktu stanowiącego podstawę nawiązania stosunku pracy.

Na koniec tej części rozważań warto jeszcze zwrócić uwagę na art. $103^{4}$ k.p., wprowadzony ustawą z 20 maja 2010 r. o zmianie ustawy - Kodeks pracy oraz ustawy o podatku dochodowym od osób fizycznych ${ }^{17}$. Z $\S 2$ tego przepisu wynika, że zawarta między stronami stosunku pracy umowa o podnoszeniu kwalifikacji zawodowych przez pracownika nie może zawierać postanowień mniej korzystnych dla niego niż regulujące te kwestie przepisy Kodeksu pracy. Przy założeniu, że postanowienia umowy o podnoszeniu kwalifikacji zawodowych składają się na treść stosunku pracy, należałoby uznać, że przepis ten stanowi kolejny przejaw mechanizmu chroniącego pracownika przed niekorzystną dla niego zmianą treści stosunku pracy.

W świetle przytoczonych wyżej przepisów można dojść do wniosku, że zasada uprzywilejowania pracownika nie ogranicza się jedynie do oceny mniej korzystnych dla pracownika postanowień wchodzących w skład treści zdarzeń prawnych wymienionych w art. 2 k.p., lecz ma ona charakter bardziej uniwersalny. Innymi słowy, zasada uprzywilejowania pracownika, którą można wyinterpretować z szeregu obowiązujących przepisów prawa pracy, ma szersze niż art. 18 k.p. brzmienie, to jest obejmuje wszelkie postanowienia umowne (wola indywidualna) oraz wszelkie postanowienia szczególnych aktów prawnych (wola kolektywna) składające się na treść stosunku pracy. Niektórzy autorzy idą jeszcze dalej, wskazując, że zasada uprzywilejowania pracownika dotyczy również jednostronnych czynności pracodawcy ${ }^{18}$.

\section{ZASADA UPRZYWILEJOWANIA PRACOWNIKA JAKO SZCZEGÓLNEGO RODZAJU NORMA PRAWNA}

Sposoby wyróżniania zasad prawa, pełniona przez nie funkcja i rola, jaką odgrywaja w systemie prawnym, były niegdyś żywo dyskutowane w polskim prawoznawstwie ${ }^{19}$. Dyskusja ta doprowadziła między innymi do wyróżnienia zasad w sensie opisowym i zasad w sensie dyrektywalnym ${ }^{20}$, który to podział

${ }^{17}$ Dz. U. 2010, Nr 105, poz. 655.

${ }^{18}$ K. Jaśkowski, w: idem, E. Maniewska, Kodeks pracy, t. 1: Komentarz, Warszawa 2009, s. 81.

19 Zob. m.in. J. Wróblewski, Zagadnienia teorii wyktadni prawa ludowego, Warszawa 1959, s. 255-260; idem, Prawo obowiazujace a ,ogólne zasady prawa”, „Zeszyty Naukowe Uniwersytetu Łódzkiego" 1965, seria I, z. 42, s. 18-20; S. Wronkowska, Sposoby pojmowania „zasad prawa” (Dyskusja w Komitecie Nauk Prawnych PAN), „Państwo i Prawo” 1972, z. 10, s. 167.

${ }^{20}$ S. Wronkowska, M. Zieliński, Z. Ziembiński, Zasady prawa. Zagadnienia podstawowe, Warszawa 1974 , s. 28 i n. 
został szeroko przyjęty również przez doktrynę prawa pracy ${ }^{21}$. Zasady prawa w znaczeniu opisowym są rozumiane jako pewien wzorzec ukształtowania jakiejś instytucji prawnej lub zespołu takich instytucji ${ }^{22}$. Zasady prawa w znaczeniu dyrektywalnym to wiążące prawnie normy systemu prawa, mające charakter nadrzędny względem innych norm tego systemu, a przy tym takie, które pełnią w tym systemie rolę szczególną, odmienną od ról wyznaczonych pozostałym normom tego systemu ${ }^{23}$. Wyjątkowa rola zasad prawa w systemie prawnym przejawia się zwłaszcza w tym, że wyznaczają one kierunek działań legislacyjnych, wspomagaja proces interpretacji prawa, wskazuja kierunki stosowania prawa, w szczególności - sposoby czynienia użytku z tak zwanych luzów decyzyjnych, a także ukierunkowuja sposób czynienia użytku z przysługujących określonym jednostkom praw ${ }^{24}$.

Zasada uprzywilejowania pracownika jest współcześnie bezspornie uznawana przez doktrynę i orzecznictwo za zasadę prawa pracy, i to mająca charakter podstawowy, co zostało dodatkowo potwierdzone przez samego ustawodawcę poprzez jej zamieszczenie w Kodeksie pracy, w rozdziale „Podstawowe zasady prawa pracy". Skoro zasada uprzywilejowania pracownika jest norma zasada, i to mająca charakter podstawowy, to w świetle dorobku ogólnej teorii prawa powinna charakteryzować się większym niż ,zwykłe” normy stopniem ogólności, a ponadto szczególną doniosłością społeczną (na co wskazuje m.in. jej podstawowy charakter). Podążając dalej tym tokiem rozumowania, można dojść do wniosku, że sama istota zasady uprzywilejowania pracownika jako normy podstawowej dla całego systemu prawa pracy implikuje, iż przenika ona cały ten system, wykraczając niejako poza ramy jednej regulacji prawnej (tj. art. 18 k.p.). W przeciwnym razie należałoby bowiem uznać, że przejawiające się $\mathrm{w}$ innych przepisach prawa pracy identyczne mechanizmy unieważniania niekorzystnych dla pracownika postanowień umownych lub regulacji prawnych, a także i mechanizmy zastępowania ich bardziej korzystnymi dla niego uregulowaniami, nie sa przejawem tej samej zasady, lecz przejawem jakichś odrębnych zasad, zawężonych do treści tych konkretnych regulacji, lub po prostu norm niebędących w ogóle zasadami prawa pracy, lecz normami „,zwykłymi”. Tak jednak nie jest, co potwierdza właśnie istota zasady uprzywilejowania pracownika jako normy o charakterze ogólnym względem innych norm i podstawowym dla całego systemu prawa pracy.

${ }^{21}$ O zasadach prawa pracy w ogólności m.in. W. Szubert, Zasady prawa pracy, „Państwo i Prawo” 1957, z. 7-8; W. Sanetra, O zasadach prawa pracy i zasadach wspótżycia spotecznego, „Państwo i Prawo” 1966, z. 1, s. 709 i n.; B. M. Ćwiertniak, Zasady prawa pracy. Zarys problematyki, w: T. Zieliński (red.), $Z$ problematyki prawa pracy $i$ polityki socjalnej, t. 3, 1980, s. 41 i n.; B. M. Ćwiertniak, Zagadnienia systematyzacji zasad prawa pracy, w: T. Zieliński (red.), Z problematyki prawa pracy i polityki socjalnej, t. 5, 1982, s. 29 i n.; T. Zieliński, Prawo pracy. Zarys systemu, cz. 1, Warszawa-Katowice 1986, s. 211-213.

22 S. Wronkowska, Z. Ziembiński, Zarys teorii prawa, Poznań 2001, s. 187.

${ }^{23}$ Ibidem. Kryteria, jakie powinna spełniać dana norma, aby można ją było uznać za zasadę prawa, podaje J. Wróblewski, w: K. Opałek, J. Wróblewski, Zagadnienia teorii prawa, Warszawa 1969, s. 92 i n. Główną cechą takich norm - zdaniem tego autora - jest posiadanie przez nie „zasadniczego” charakteru. Norma posiada natomiast charakter ,zasadniczy”, jeśli spełnia jedno z następujących kryteriów: ma charakter hierarchicznie lub treściowo nadrzędny względem innych norm albo pełni szczególną rolę w ramach konstrukcji pewnej instytucji prawnej bądź posiada szczególną doniosłość społeczną.

${ }^{24}$ S. Wronkowska, Z. Ziembiński, Zarys teorii prawa..., s. 188. 


\section{WYKŁADNIA PRZEPISU ART. 18 K.P. ZE SZCZEGÓLNYM UWZGLEDNIENIEM DYREKTYW FUNKCJONALNYCH I CELOWOŚCIOWYCH}

Przedstawione dotychczas argumenty miały na celu wykazać, że sposób rozumienia zasady uprzywilejowania pracownika nie powinien być ograniczany jedynie do rezultatu wykładni przepisu art. 18 k.p. Warto jednak podkreślić, że nawet jeśliby przyjąć stanowisko całkowicie odmienne, iż zasada uprzywilejowania pracownika jest wyrażona tylko i wyłącznie w art. 18 k.p. i tylko ten przepis wyznacza granice jej oddziaływania, to i tak nie można by dojść do wniosku, że stosowanie tego przepisu jest ograniczone tylko do jego literalnego brzmienia.

Wnioski, do jakich dochodzi interpretator tekstu prawnego, sa jednak w pewnym stopniu uzależnione między innymi od koncepcji i rodzaju wykładni, na jakiej oparł on proces odkodowywania normy prawnej z przepisów. Tam bowiem, gdzie niektórzy kończa swą interpretację w myśl koncepcji klaryfikacyjnej i zasady clara non sunt interpretand ${ }^{25}$, inni na podstawie koncepcji derywacyjnej ${ }^{26}$ idą dalej w celu sprawdzenia poprawności rezultatów wykładni językowej w świetle dyrektyw funkcjonalnych i systemowych. Relacje zakresowe między tymi dwiema koncepcjami mają się tak, że żaden z problemów rozpatrywanych na gruncie koncepcji klaryfikacyjnej nie pozostaje poza zakresem koncepcji derywacyjnej, ta ostatnia zaś uwzględnia rozwiązania również tych problemów, które umykają tej pierwszej. Dlatego też dalsze uwagi dotyczące interpretacji przepisu art. $18 \mathrm{k}$.p. zostaną poczynione w nawiązaniu do koncepcji derywacyjnej w wersji zaprezentowanej przez Macieja Zielińskiego $^{27}$. W myśl zaś tego ostatniego ujęcia proces wykładni dzieli się na trzy fazy: porządkująca, rekonstrukcyjną i percepcyjną. Odkodowując zatem normę, interpretator dokonuje określonych czynności najpierw na poziomie przepisu (faza porządkująca), później w celu uzyskania wyrażenia normokształtnego zupełnego syntaktycznie, logicznie i treściowo (faza rekonstrukcyjna), a na końcu w celu uzyskania ostatecznego brzmienia normy prawnej (faza percepcyjna).

W myśl przepisu art. $18 \S 1$ k.p.: „,Postanowienia umów o pracę oraz innych aktów, na których podstawie powstaje stosunek pracy, nie moga być mniej korzystne dla pracownika niż przepisy prawa pracy". Jak już była mowa, opierając się przy interpretacji jedynie na dyrektywach językowych wykładni, można dojść do wniosku, że norma zakodowana w tym przepisie ogranicza się tylko do zdarzeń wyczerpująco wskazanych w art. 2 k.p. (tj. podstaw nawiązania stosunku pracy). Zwolennicy zasady clara non sunt interpretanda, a także ci, którzy opierają proces wykładni tylko lub głównie na dyrektywach językowych, na tym by zakończyli. W myśl jednak koncepcji derywacyjnej powinno się pójść dalej w celu weryfikacji uzyskanej jednoznaczności językowej w świetle między innymi dyrektyw funkcjonalnych. Innymi słowy, należy zadać pytanie,

\footnotetext{
${ }^{25}$ J. Wróblewski, Zagadnienia teorii wyktadni..., passim.

${ }^{26}$ Ideę tej koncepcji przedstawił Z. Ziembiński, Logiczne problemy prawoznawstwa, Warszawa 1966, s. 208 .

${ }^{27}$ M. Zieliński, Wyktadnia prawa. Zasady. Reguty. Wskazówki, Warszawa 2002.
} 
czy przyjęcie takiego językowego znaczenia normy prawnej nie jest sprzeczne $\mathrm{z}$ wyznawanym przez racjonalnego aksjologicznie prawodawce systemem wartości. Chodzi oczywiście o wartości mające charakter fundamentalny dla danej instytucji prawnej czy dziedziny prawa, a w szczególności te, które legły $\mathrm{u}$ podstaw interpretowanego przepisu ${ }^{28}$. Taką wartością $w$ przypadku art. 18 k.p. jest między innymi potrzeba ochrony pracownika jako słabszej ekonomicznie strony stosunku pracy przed niekorzystna dla niego umowną zmiana jego treści, w porównaniu ze standardami wyznaczonymi przez przepisy prawa pracy. Jeśli zatem udałoby się wykazać, że przyjęcie literalnego brzmienia normy zakodowanej w art. $18 \S 1 \mathrm{k} . p$. burzyłoby leżące u podstaw tej regulacji wartości, należałoby przełamać znaczenie językowe i dać pierwszeństwo założeniom aksjologicznym. Innymi słowy, należałoby dokonać wykładni rozszerzającej, odwołując się do wartości, jakie przyświecały prawodawcy tworzącemu interpretowaną regulację ${ }^{29}$.

W omawianym przypadku wydaje się, że taki zabieg jest nie tylko możliwy, lecz także konieczny, aby zapewnić realizację wspomnianych wyżej wartości. Zawężenie bowiem normy zakodowanej w przepisie art. $18 \S 1 \mathrm{k} . \mathrm{p}$. do oceny jedynie tych postanowień, które zawarte są w umowach lub aktach będących podstawą nawiązania stosunku pracy, może doprowadzić do sytuacji, w której treść umowy o pracę (lub innej podstawy nawiązania stosunku pracy) nie będzie dla pracownika mniej korzystna niż przepisy prawa pracy, jednakże sumaryczna treść stosunku pracy będzie dla niego zdecydowanie niekorzystna w porównaniu ze standardem zapewnionym mu przez przepisy prawa pracy. Można sobie bowiem dla przykładu wyobrazić sytuację, że pracownik w umowie o pracę ma zapewnioną płacę $\mathrm{w}$ wysokości czterokrotności wynagrodzenia minimalnego, w sytuacji kiedy obowiązujący w zakładzie pracy regulamin wynagradzania wymaga ustalenia wynagrodzeń na poziomie co najmniej równym trzykrotności płacy minimalnej, i to bez jakichkolwiek wyjątków. Ten sam jednak pracownik w zawartej z pracodawca umowie o wspólnej odpowiedzialności materialnej ma wskazany obszerny katalog sytuacji wyjątkowych, w których jego wynagrodzenie będzie na poziomie niższym niż regulaminowy, ale wyższym niż gwarancje ustawowe. Postanowienia zatem umowy o pracę będa w myśl art. 18 k.p. dla pracownika korzystniejsze niż przepisy prawa pracy (regulamin i ustawa), jednak sumaryczna treść stosunku pracy, ukształtowana również przez umowę o wspólnej odpowiedzialności materialnej, może być dla niego mniej korzystna niż standard regulaminowy. Zawężenie zatem mechanizmu z art. 18 k.p. tylko do postanowień zawartych w zdarzeniach kreujących stosunek pracy oznaczałoby de facto, że prawodawca uzależnił zakres ochrony pracowników od tego, czy dany niekorzystny dla nich zapis znajduje się w umowie o pracę, czy też w innej umowie związanej ze stosunkiem pracy. Takie

\footnotetext{
${ }^{28}$ Przełamanie bowiem językowego znaczenia przepisu może mieć miejsce tylko w ściśle określonych przypadkach i tylko wtedy, kiedy istnieje ku temu mocne uzasadnienie aksjologiczne. Szerzej na ten temat m.in. Z. Ziembiński, Podstawowe problemy prawoznawstwa, Warszawa 1980, s. 292 i n.; L. Morawski, Zasady wyktadni prawa, Toruń 2005, s. 75 i n.

${ }^{29} \mathrm{Na}$ temat wykładni rozszerzającej zob. w szczególności następujące orzeczenia: wyrok TK z 28 czerwca 2000 r., K 25/99, OTK 2000, nr 5, poz. 141; wyrok SN z 8 kwietnia 2001 r., V KKN 281/00, OSNKW 2002, nr 7-8, poz. 56; uchwała SN z 20 czerwca 2000 r., I KZP 14/00, OSNKW 2000, nr 7-8, poz. 59; uchwała SN z 7 marca 1995 r., III AZP 2/95, SNAP 1995, nr 15, poz. 182.
} 
stanowisko jest nie do przyjęcia. Odwołując się zatem do racjonalności aksjologicznej prawodawcy, a także do dyrektyw celowościowych wykładni, można stwierdzić, że zamiarem ustawodawcy było raczej objęcie ochroną całokształtu treści stosunku pracy, nie zaś jedynie tej części, która wynika z treści umowy o pracę lub innych wskazanych w art. 2 k.p. zdarzeń prawnych. Z tego względu należałoby przyjąć wykładnię rozszerzająca, uznając, że norma zasada odkodowana z przepisu art. $18 \S 1$ k.p. umożliwia ocenę również innych postanowień umownych niż te wskazane w art. 2 k.p., pod warunkiem jednak, że składają się one na treść stosunku pracy.

Przyjęcie powyższego stanowiska wydaje się bardziej celowe i niejako lepiej dopasowane do specyfiki stosunku pracy niż odpowiednie stosowanie przepisów Kodeksu cywilnego. Można by bowiem również uznać, że art. 18 § 1 k.p. ogranicza się tylko do zdarzeń prawnych literalnie w nim wskazanych, a wszelkie inne postanowienia umowne należy oceniać w świetle odpowiednio stosowanego przepisu art. 58 k.c. w zw. z art. 300 k.p. ${ }^{30}$ Odwołanie się do art. 58 k.c. wymagałoby jednak przeprowadzenia $\mathrm{w}$ ramach ,odpowiedniego stosowania” dwóch zabiegów dopasowujących zrekonstruowaną na jego podstawie normę do specyfiki stosunku pracy. Po pierwsze, trzeba by przyjąć, że art. $58 \S 1$ k.c., mówiący o sprzeczności z ustawą, rozciąga się również na przepisy specyficznych źródeł prawa pracy (np. regulaminu wynagradzania), które jednak ustawa ani innym aktem powszechnie obowiązującym nie są. Po drugie, należałoby uznać, że przepis ten umożliwia zastąpienie nieważnych postanowień umownych odpowiednimi przepisami prawa pracy, znajdujacymi się również w specyficznych aktach prawnych (np. w regulaminie wynagradzania). Dopuszczalność tak znacznej modyfikacji brzmienia przepisu art. 58 k.c. może budzić uzasadnione wątpliwości. Niezależnie jednak od tego wydaje się ona sztuczna, a przede wszystkim niepotrzebna. Aby bowiem odwołać się do art. 58 k.c., należy wykazać, że sprawa jest nieuregulowana przepisami prawa pracy (art. 300 k.p.). Pierwszeństwo zatem powinno przysługiwać stosowaniu przepisów prawa pracy, a do Kodeksu cywilnego należałoby odwoływać się jedynie wyjątkowo.

\section{WNIOSKI}

Na podstawie powyższych ustaleń, należy uznać, że niezależnie od punktu, z jakiego dokonuje się oceny relacji zasady uprzywilejowania pracownika do treści art. 18 k.p., nasuwa się jeden wniosek. Wskazana tu zasada może znaleźć zastosowanie do wszelkich postanowień umownych, które składają się na treść stosunku pracy, bez względu na to, czy wynikaja one z podstaw jego nawiązania. Wynika to z tego, że zasada uprzywilejowania pracownika chroni całokształt treści stosunku pracy, nie zaś tylko ten fragment, który wynika z treści umowy o pracę lub treści innych zdarzeń prawnych, na podstawie których powstaje stosunek pracy. Taki wniosek, mimo literalnego brzmienia przepisu art. 18 k.p., nasuwa się przede wszystkim po przeprowadzeniu pełnego procesu wykładni, a w szczególności odwołaniu się do dyrektyw funkcjonalnych wskazujących istotne wartości i cele, jakie przyświecały racjonalnemu prawodawcy przy

\footnotetext{
${ }^{30}$ Tak m.in. M. Swiątkowski, Kodeks pracy..., s. 511.
} 
tworzeniu interpretowanej regulacji. Odwołanie się do odpowiedniego stosowania przepisu art. 58 k.c. $\mathrm{w}$ zw. $\mathrm{z}$ art. 300 k.p., mimo że prowadzące $\mathrm{w}$ praktyce do podobnych rezultatów, wydaje się niecelowe, niepotrzebne, a nawet niemożliwe w świetle art. 300 k.p. Sprawa bowiem jest uregulowana w art. 18 k.p., tyle że widać to dopiero na poziomie dyrektywnym, a nie deskryptywnym. Dodatkowo, zaprezentowane tu stanowisko wspiera również fakt, że zasada uprzywilejowania pracownika jest normą dającą się odtworzyć również z szeregu innych przepisów prawa pracy, a nawet z samego charakteru dominujących w tej gałęzi prawa norm. Wskazuje to na jej ogólny, uniwersalny i podstawowy dla całego prawa pracy charakter, wykraczający poza ramy jednej regulacji prawnej. Innymi słowy, art. 18 k.p. stanowi jedynie pewien przejaw zasady uprzywilejowania pracownika, która przenikając cały system prawa pracy, znajduje zastosowanie wszędzie tam, gdzie treść stosunku pracy (nie zaś ogólna sytuacja prawna) zostaje ukształtowana mniej korzystnie dla pracownika, niż wynika to z przepisów prawa pracy. De lege ferenda należałoby zatem postulować zmianę brzmienia art. 18 k.p. przez umieszczenie w nim wyraźnego wskazania, że zawarty tam mechanizm ochronny dotyczy również czynności prawnych związanych ze stosunkiem pracy, o ile modyfikują one jego treść.

Osobnym zagadnieniem, zaznaczonym jedynie we wstępie, jest ustalenie, kiedy i na jakich warunkach zawierana przez strony czynność prawna modyfikuje treść stosunku pracy. Sprawa nie jest wcale oczywista, w szczególności w świetle zawieranych przez strony umów nienazwanych lub co prawda nazwanych, jednak uregulowanych przepisami prawa cywilnego (np. umowa o wydanie weksla). Problematyka ta nie zostanie tu jednak rozwinięta, albowiem ze względu na swoją złożoność wymaga osobnego omówienia.

mgr Mikotaj Rylski

Uniwersytet Szczecinski

\author{
ADDITIONAL AGREEMENTS BETWEEN PARTIES \\ TO AN EMPLOYMENT RELATIONSHIP \\ IN LIGHT OF THE EMPLOYEE'S PREFERENTIAL TREATMENT
}

Summary

The paper deals with a controversial issue of the admissibility of evaluation, in light of the employee's preferential treatment, of additional stipulations of contracts signed by parties to an employment relationship, which do not form the underlying condition for their execution. The main aim of the work is to prove that the rule of the employee's preferential treatment, contrary to the literal content of article 18 of the Labour Code should be understood in broader terms: as one that protects the entire work relationship including additional agreements.

In principle, there are three types of argument that provide a rationale for the above thesis. Firstly, it is the nature of the rule of the employee's preferential treatment which acts as a general and basic norm in the labour law, and the role it plays in the Labour Code. Secondly, it is the mechanisms characteristics of this rule that may be found in work regulations other than those referred to in the above mentioned article 18, and in particular in the very nature of the semi imperative norms dominating in the labour law. Thirdly, it is the result of the entire process of interpretation of article 18 of the Labour Code, including, in particular, the functional and purposeful directives. 
Copyright of Journal of Law, Economics and Sociology is the property of Faculty of Law and Administration of Adam Mickiewicz University in Poznan and its content may not be copied or emailed to multiple sites or posted to a listserv without the copyright holder's express written permission. However, users may print, download, or email articles for individual use.

Właścicielem praw autorskich do „Ruchu Prawniczego, Ekonomicznego i Socjologicznego” jest Wydział Prawa i Administracji Uniwersytetu im. Adama Mickiewicza w Poznaniu. Zawartość czasopisma nie może być kopiowana, przesyłana do innych stron internetowych bądź zamieszczana na blogach bez pisemnej zgody wydawcy. Niemniej artykuły można drukować, kopiować lub przesyłać w formie elektronicznej na własny użytek. 